\title{
Selected Aspects of Social and Legal Protection of Children: Expert Approach versus Public Opinion
}

\author{
Soňa Vávrová ${ }^{1}$ \\ Jitka Vaculíková ${ }^{2}$ \\ Jan Kalenda ${ }^{3}$
}

\section{Contact to authors}

${ }^{1,2,3}$ Tomas Bata University in Zlín Faculty of Humanities

nam. T. G. Masaryka 5555

76001 Zlín

vavrova@fhs.utb.cz

jvaculikova@fhs.utb.cz

kalenda@fhs.utb.cz

\section{Kontakt na autora}

1,2,3 Univerzita Tomáše Bati ve

Zlíně

Fakulta humanitních studií

nám. T. G. Masaryka 5555

76001 Zlín

vavrova@fhs.utb.cz jvaculikova@fhs.utb.cz kalenda@fhs.utb.cz

Copyright (C) 2016 by the author and publisher, TBU in Zlín.

This work is licensed under the Creative Commons Attribution International License (CC BY).

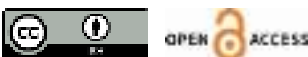

\begin{abstract}
Social and legal protection of children can be approached from two general positions. The first is expert discourse in the form of various scientific schools or epistemic communities and the other is the position of public opinion. The purpose of this study is to show both the coexistence and potential contradictory nature of these two approaches on selected current issues of social and legal protection of children (boundary of criminal liability, institutional or protective care and replacement care of parentless children). While mapping the expert discourse is based on scientific knowledge of the issue, mapping the public opinion uses data of a representative inquiry aimed at the study of opinions of the Czech population in 2015 $(n=1.050)$. The study concludes that though public opinion and expert discourse regarding the replacement care of parentless children are to some extent in agreement, there is a difference of opinion on the boundary of criminal liability and institutional or protective care of children and youth with problematic behaviour.
\end{abstract}

Keywords: social and legal protection of children, boundary of criminal liability, institutional care, replacement care of parentless children, social policy, public opinion, expert discourse

\section{Vybrané otázky sociálně-právní ochrany dětí: Odborný přístup versus veřejné mínění}

Abstrakt: K otázkám sociálně-právní ochrany dětí Ize přistupovat na základě dvou obecných pozic vědění. První je prrístup odborného diskursu $v$ podobě různých vědeckých škol či tzv. epistemických komunit, zatímco druhou je pozice veřejného mínění. Cílem této studie je na vybraných aktuálních problémech sociálně-právní ochrany dětí (hranice trestní odpovědnosti, ústavní či ochranné výchovy a náhradní péče) ukázat koexistenci a potenciální kontradikčnost těchto dvou přístupů. Pro mapování odborného diskursu vycházíme z vědeckých poznatků o problematice, zatímco pro mapování veřejného mínění používáme data $z$ reprezentativního šetření názorů české populace z roku 2015 ( $n=1,050$ ). Studie dochází k závěru, že veřejné mínění zastává jiné stanovisko vzhledem $k$ hranici trestní odpovědnosti a ústavní či ochranné výchovy než odborný diskurs, zatímco $v$ prípadě náhradní péče se $s$ ním $v$ některých bodech shoduje.

Klíčová slova: sociálně-právní ochrana dětí, trestní odpovědnost, ústavní výchova, náhradní péče, sociální politika, veřejné mínění, odborný diskurs 
Vávrová, Vaculíková, \& Kalenda / Selected Aspects of Social and Legal Protection of Children...

\section{Introduction}

Social and legal protection of children is laid down in Czech law in the 1998 legislative Act No. 359/1999 Coll. (2016). It can be approached from two general knowledge positions. ${ }^{40}$ The first is the approach of expert discourse, to which different groups of scientists or epistemic communities contribute (Grundman \& Stehr, 2012; Knorr-Cetina, 1999; Stehr, 2001; Stehr \& Grundman, 2011). This defines the notions of social and legal protection of children and social and social pedagogical work by expert language, and is involved in the formation of social policy through recommendations to the state apparatus. The second is the public opinion, the popular discourse, produced by various social groups defined by heterogeneous socio-demographic features, such as social status, education or age, and which may take individual standpoints to the issues of social and legal protection of children. Public opinion is equally important for social policy formation as it exerts pressure on political representation through media and various interest groups by which the political agenda of the social state is affected. In this way, problems are approached and resolved - or not (see, for example, Best, 2008; Dearing \& Everett, 1996; McCombs, 2009; Škodová \& Nečas, 2009). Thanks to its power and intensity, the public opinion opens current issues related to social and legal protection of minors in waves (often in connection with media cases), thus contributing to implementation of or, alternatively, prevention of particular changes.

The purpose of this study is to address selected current issues of social and legal protection of children: (1) Boundary of criminal liability, (2) Institutional or protective care and (3) Replacement care of parentless children, and then to show the coexistence of these two approaches and their frequent contradictory nature, which may create obstacles to addressing and resolving the issues. This is especially true where the public opinion opposes the professional discourse and its recommendations.

The present contribution focuses on social and legal protection, which is part of social and social pedagogical work. Here social and pedagogical work overlap and their representatives and approaches contribute to the establishment of professional practice and formation of a media image of the social reality. Teachers and social workers actively contribute to formation of social policy not only by initiating the desired methodological and legislative changes but also by their actual implementation. Thus, they become important social players affecting both expert and public discourse and are not to be overlooked.

To study the issue of social and legal protection, we have selected the aforementioned three areas whose legislative background is undergoing multiple changes. This suggests that these are important issues, ideal to study and document whether the premise of overlaps between the two discursive positions is based on real facts or not. The selection of the three issues brings methodological advantages as well as disadvantages. The advantage is that the existence of two different knowledge positions will be studied based on three mutually independent cases. Were we to focus on a single theme only (even were we to subject it to profound analysis), we would still run the risk of selecting a case in which there is chance coexistence of the expert and the popular discourse. ${ }^{41}$ On the other

40 In $\S 1$, the socio-legal protection is defined as: Protection of the rights of a child to proper development and education, protection of legitimate interests of a child, including protection of its assets and activities leading to restoration of disturbed family functions and ensuring substitute family environment for a child who cannot be permanently or temporarily reared in their own family.

41 The use of three deliberately selected cases based on a methodological approach using a small number of surveyed units - so-called "Small-N case based research" (Goertz \& Mahoney, 2012; Ragin, 2000, 2009) allows not only the formulation of questions that would otherwise be too general and outside adequate empirical terrain, but which also allows to compare cases among themselves. This is the main advantage compared with an approach that is based on the concept of individual case studies (Yin, 2002), which in Czech studies are most often used. Systematic comparison between theories in specifically selected cases 
hand, the greatest threat to our selection is our necessary inability to describe in sufficient detail the individual issues. The limited scope of this study deprives the authors of the possibility to reconstruct all three discourses properly. Therefore, often just the key theses on which the discourses are based are selected with reference to works of the authors representing them.

The main aim of this study can therefore be redefined in terms of three mutually interconnected objectives. First of all, our analysis of the expert and the popular discourse in relation to the three aforementioned thematic areas will show expert and non-expert approach to these areas. Second, our analysis of the data of the special inquiry focused on the opinions of adult Czech population will reveal the main aspects of public opinion on these issues, including its inner segmentation by key socio-demographic features (gender, age, education, etc.). And third, our comparison of the obtained results will show key similarities and differences between the two approaches, as well as their implications for social and socio-pedagogical work in the area of social and legal protection of children.

The test structure will reflect the logic of these three objectives. Following a brief introduction of our theoretical assumptions, we will discuss the positions taken by the expert and the popular discourse towards social and legal protection of children. The next chapter will introduce the methodology and results of the representative public opinion inquiry. And finally, by way of conclusion, we will discuss the mutual relationship between the expert discourse and the public opinion, including their implications for social and social-pedagogical work.

\section{Theoretical assumptions}

Even though recently a whole range of aspects of social and socio-pedagogical work in the Czech Republic is systematically reflected by the expert discourse (see, for example, Bakošová, 2008; Gulová, 2012; Hrbáčková \& Petr Šafránková 2015; Punová, 2015; Stanoev, 2014; Vávrová \& Kroutilová Nováková, 2015), considerably less attention is paid to public opinion and current social and socio-pedagogical issues (see, for example, Horáková, 2016). That is despite the fact that this is the very public opinion that is one of the key agents driving construction of social problems (Best, 2008; Loseke, 1999; Spector \& Kitsuse, 1977, Stone, 2011) - i.e., deciding how relevant they are, whether they shall be addressed and, if so, how.

This role of public opinion leads certain authors (see, for example, Dearing \& Everett, 1996; McCombs, 2009; Škodová \& Nečas, 2009) to the conclusion that public opinion, formed into a certain thematic agenda, represents an important force affecting political and state decision-making, which may result in the deduction that even the agendas of social policy and socio-pedagogical work are affected. The questions of social and socio-pedagogical work often become controversial social themes about which the public forms opinions and to which politicians must respond. What is equally important is that these standpoints may differ from professional practical opinion (of social workers/teachers) or scholarly opinion (research on the social and legal protection of children). Therefore, these may stand in opposition to the agenda of the "knowledge-driven" social policy.

Thus, in reality, two general approaches to social and socio-pedagogical work coexist, representing different forms of knowledge and different approaches to (co)creation of social policy and addressing its issues. On the one hand, there is the expert approach typical of specialists from practice or academic spheres, the so-called "expert apparatus" (Giddens, 1998), while on the other there is the public opinion approach, which represents popular forms of knowledge in the form of opinions and positions, in turn informed by age, education or socio-economic status of individuals.

can, in the long run, create prerequisites for formulating middle range theory, as highlighted, for example, in Glaeser (2006) and Vaughan (2014). 
The present study tries to view both approaches not only in the context of their mutual relation but also with regard to their consequences for social and socio-pedagogical work. This presents a rather unexplored field. In this respect, we will not only discuss the nature of both approaches to the selected themes but also empirically analyse them. Examples of (1) boundary of criminal liability, (2) institutional or protective care and (3) replacement care of parentless children will be used to show what the position of the current professional approach is and what the public thinks about them that is, what the public opinion is.

\section{Expert vs. popular discourse in selected areas of social and legal protection of children}

As is the case in most European countries, Czech society addresses certain controversial themes related to social and legal protection of children in waves. The target group - children, i.e. minors under 18 years of age - deserves special attention as one of the "vulnerable" target groups due to the younger ages. ${ }^{42}$

The role of professional discourse and public opinion (popular discourse) will be demonstrated in a couple of problematic issues surrounding social and legal protection of children and subjected to recent public discussion with legislative intervention. These issues are represented by the boundary of criminal liability and the related orders of institutional or protective care and subsequent replacement care.

\subsection{Boundary of criminal liability}

In preparation for the enactment of the "new" legislative act, the New Civil Code (Act No. 89/2012 Coll., 2015; effective from 1 January, 2014) the boundary of criminal liability became the subject of wide public discussion. Pursuant to $\S 109$ of the Criminal Code (Act No. 40/2009 Coll., 2016), the criminal liability of adolescents and sanctions imposed on them are stipulated by the act on judicature for youth (Act No. 218/2003 Coll., 2016). This classifies youth as children (up to 15 years of age) and adolescents (from 15 to 18 years of age). ${ }^{43}$ Thus, the boundary of criminal liability as laid down by Czech law is 15 years of age.

A discussion on the boundary of criminal liability is often started by a "shocking" case with wide media coverage, as for instance in England in 2010, when the public was surprised by the case of an eight-year-old girl raped by two ten-year-old boys (Arthur, 2012). Although the legislative boundary of criminal liability in England and Wales is 10 years ("States Lowering Age," 2016), this case posed the question whether minors committing this criminal act should be treated as adults who committed the same offence (Arthur, 2012). The main issue here is that the law and criminal liability system is based on the assumption that man is able to understand and foresee consequences of his acts and make decisions on the basis of his understanding and free will. The professional and the popular discussions are linked by the question of whether there is an age limit which, when reached, makes the individual capable of informed decisions based on free will.

42 According to $\S 30$ paragraph 1 of the Act No. 89/2012 Coll. (2015), one becomes full and capable adult at the attainment of eighteen years of age. According to $\S 31$, it is considered that any minor who has not yet acquired full legal capacity is eligible to legal appraisal regarding his mental and moral maturity given his age and status as a minor.

43 See $\S 5$ paragraph 1 of Act No. 218/2003 Coll. (2016), which defines the responsibilities of a juvenile as follows: a teenager who, at the time of the offense has neither reached the intellectual and moral maturity to be able to recognize its unlawfulness nor control his conduct, shall not be held criminally responsible. According to $\S 6$ paragraph 1 and 2 of this Act, an offense committed by a juvenile is called an offense and unless the law otherwise indicates, applies to the assessment of the offense committed by the juvenile penal code. 
Many authors (for example Cipriani, 2009; Elliott, 2011; Farmer, 2011; Bateman, 2014) hold that because children's personal autonomy is limited (as is their ability to make decisions from free will), it is in principle incorrect to impose criminal liability on children. A similar statement can be found in Hollingsworth (2013), who adds that childhood is the period of growth into complete autonomy and thus children are not to be taken as fully autonomous. Arthur (2012) and McDiarmid (2013) extend this argument by saying that children making decisions are less competent to assess whether their decision and their subsequent action is clearly correct or incorrect. Their orientation in the moral and legal systems of society is not yet fully developed when compared to young adults (18-24 years of age). Grisso and others (2003) document with empirical data that the ability of children (11-13) to cope with litigation differs considerably from young adults (18-24). While the accused adults are able to resist the stress of litigation, the accused children tend to make a confession more quickly under that stress.

By contrast, as stated by the Child Rights International Network ("States Lowering Age," 2016), many countries show an opposite trend: lowering the boundary of criminal liability, accompanied by public discussions on the theme. Similar trends can be observed in the domestic environment where, for example, a member of parliament, Mr. Tejc, stated in a TV discussion that he would like to submit a proposal for lowering the criminal liability boundary age from 15 to 13 for selected criminal acts ("Tejc navrhuje," 2016). This proposal met with a negative response from both other members of parliament and members of the legal community ("Congress Legislative Space," 2016).

The expert discourse supported their negative approach not only through the findings of the developmental psychology (see, for example, Erikson, 2015; Thorová, 2015; Říčan, 2014; Klusák, 2014), but also through statistical data documenting the overall reduction of criminality among children and youth. This was corroborated at the seminar on Age boundary of criminal liability in the light of recent events held by PSP CR (on 29 March 2016). ${ }^{44}$ Identical arguments can also be encountered earlier, when in 2008 the server iDnes.cz reported that the opinion of certain experts was that the boundary of criminal liability does not need to be lowered.$^{45}$ This is further documented by Svatoš (2013), who also argues against lowering the age of criminal responsibility (see Figure 1).

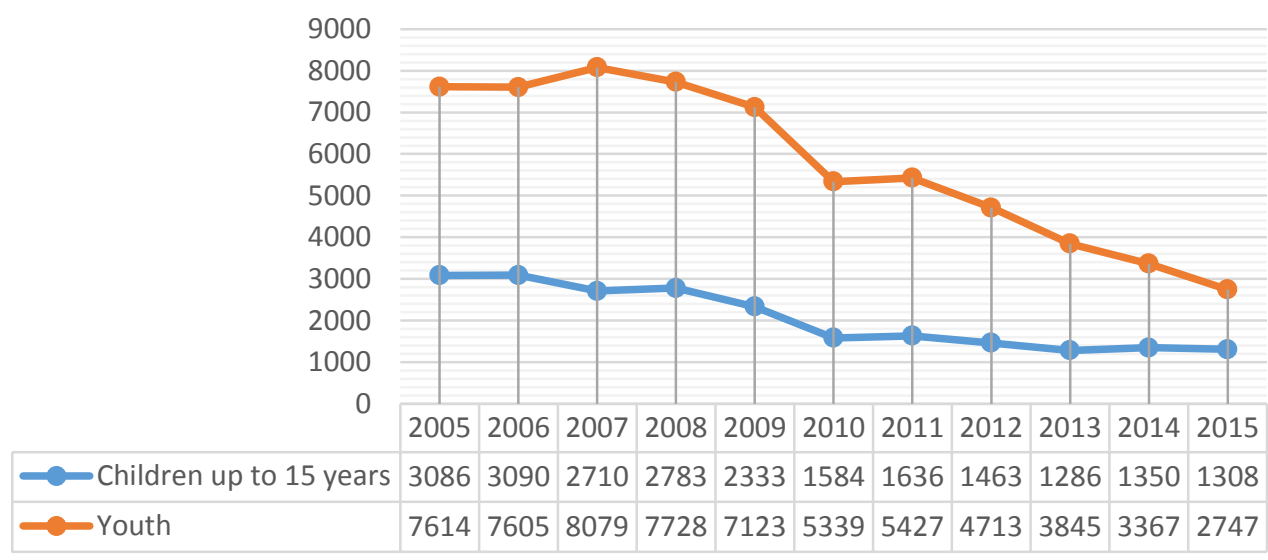

Source: Statistical Data of the Police Presidency of the Czech Republic (In Hulmáková, 2016) Adapted by authors.

Figure 1 Criminality of children and youth in the years 2005 to 2015

The above allows a deduction of the existence of two approaches: one argues for contesting criminal liability of children and denies the need for lowering the criminal liability age limit, while the other focuses on increasing it.

\footnotetext{
44 See the age responsibility (Hulmáková, 2016).

45 See Válková and Hulmáková (2008).
} 
Vávrová, Vaculíková, \& Kalenda / Selected Aspects of Social and Legal Protection of Children...

\subsection{Institutional or protective care and replacement care of parentless children}

The boundary of criminal liability is closely connected with another area reflected in this study: institutional or protective care of children and youth with problematic behaviour (truancy, theft, use of addictive substances, criminal behaviour, etc.). Institutional care cannot be strictly separated from replacement care, which is often presented as its more appropriate alternative or counterpart. These two themes are analysed together in the context of the current stage of the discourse, which currently favours de-institutionalisation and stepwise replacement of institutional care with other more appropriate variants. Due to the given reality, we will discuss these two subjects together as well.

Institutional and protective care in the Czech Republic are part of institutional care, i.e. care provided by a certain type of resident facility, such as a diagnostic institute, children's home with school or penitentiary.

Protective care, pursuant to Act No. 218/2003 Coll. (2016), is classified together with protective therapies, detention and property confiscation as protective measures falling exclusively within the limits defined by the quoted act, and may only be imposed on the basis of the relevant provisions of the act. Protective care is imposed in cases ( $\$ 22)$ when: (1) the young individual's care has not been properly arranged for, (2) the young individual's care has been neglected or (3) the environment in which the young individual lives does not guarantee his or her proper care, and when the situation cannot be resolved by imposition of disciplinary measures pursuant to the act on social and legal protection of children (Act No. 359/1999 Coll., 2016). The length of protective care is limited to 18, or exceptionally 19 years of age. The purpose of the protective measures, and thus of the protective care, is positive impact on mental, moral and social development of the young individual and protection of the society against the criminality of the youth ( $\$ 21$, Ibid).

Institutional care may come before or after protective care. The objectives of institutional care are more general in their essence and their role does not include protection of the society, which is emphasized in the case of protective care. One can therefore say that this type of care is used when the child's care or physical, mental or intellectual condition or proper development are seriously threatened or disrupted to the extent that it damages interests of the child or when there are serious reasons why the parents cannot secure their child's care (§971 (1) of Act No. 89/2012 Coll., 2015), where the court must always consider as the primary option entrusting the child to the case of another natural person, i.e. replacement family care.

According to data of 2014/2015 ("Tab. č. 65," 2015), there are in the Czech Republic 214 facilities for institutional and protective care, of which 144 are children's homes, 29 are children's homes with a school, 28 are penitentiaries and 13 are diagnostic institutes. These institutions take care of 6.495 children and young people, of whom 4.949 are under court order for institutional care and 130 are under court order for protective care.

Replacement care covers (1) custody by another natural person, (2) legal guardianship, (3) foster care and (4) child care (Act No. 89/2012 Coll., 2015). The following text will classify replacement care and care on the basis of the environment in which it is provided. To that end, replacement care differentiates between natural social environment (most resembling an ordinary family environment) and institutional environment. A Child's placement outside his or her original family must always be decided by court ... with replacement family care preferred to institutional care placement (Chrenková, Cilečková, \& Hašková, 2015, p. 39).

There has been wide expert discussion in Czech society for decades concerning both the appropriateness and potential negative impact of institutional care on the future life of the child (see, for example, Matějček \& Dytrych, 1994; Kovařík, 1998; Bittner et al., 2007; Kubíčková, 2011; Běhounková, 2012; Vávrová, Hrbáčková, \& Hladík, 2015). Individual forms of replacement care with an emphasis on foster care are often seen as an alternative to institutional care (see, for example, Bauer, 1995; Matějček, 1998; Novák, 2008; Zezulová, 2012; Sobotková \& Očenášková, 2013; 
Chrenková, Cilečková, \& Hašková, 2015). There are also studies investigating opinions of various stakeholder groups (see, for example, Vávrová, Musilová, \& Polepilová, 2014; Vávrová \& Kroutilová Nováková, 2015). The harmful effect of children's stays in big institutional care facilities is emphasized by the international organisation LUMOS (with offices in the Czech Republic) and documented by experts with more than 80 years of research pointing out retardation of cognitive, social and physical development of children raised in institutional care for most of their most important evolution stages. ${ }^{46}$

The mainstream expert discourse currently agrees that changes in the area of replacement care of threatened children are necessary and should be governed by the policy of de-institutionalisation, i.e., the policy of minimising the institutional or protective care placement in residential facilities of children and young people in need of replacement care. ${ }^{47}$ However, the media often points out the pitfalls of this process (see, for example, Janský, 2009). Some discussions also bring arguments that most children living in children's homes show no interest in receiving foster parents (see, for example, Slavíková \& Horáková, 2014). Still, in the broadest sense, the expert discourse seems to resonate with the popular discourse.

In conjunction with the development of care of threatened children and youth, the Ministry of Labour and Social Affairs ("Národní akční plan," 2009; "Návrh opatření," 2009) issued the National Action Plan for Transformation and Unification of the System of Care of Threatened Children for the Period 2009-2011 and the Proposed Measures for Transformation and Unification of the System of Care of Threatened Children - Basic Principles. Subsequently, in 2012, the Ministry issued the National Strategy of Child Rights Protection, in which it defined its basic principles and the principles of care of threatened children. ${ }^{48}$ In the same year, the Action Plan for Implementation of the National Strategy of Child Rights Protection for 2012-2015 was issued. All of these strategic documents deal with children's rights, including the right to family care. Reforms to replacement care bring about fundamental changes responded to by professionals as well as the general public. Whether they are partial changes (for example, cancellation of the institute of baby homes, transformation of children's homes or introduction of temporary foster care institute) or overall transformation of the whole system of care, both discourses see the need for the change. They differ, however, on how to implement that change. Reflections surrounding the current issue of replacement care and care appear in many published articles (see, for example, Toman, 1994; Svobodová, 2003; Cilečková, 2014; Vávrová \& Kroutilová Nováková, 2015). Thus, the de-institutionalisation process develops its legitimacy through both expert and popular discourse.

A little less attention is paid to institutional or protective care of children with problematic behaviour (see, for example, Pilař, 2005; Svoboda et al., 2012; Janský, 2014). This issue is generally discussed in waves, which are initiated from wide media coverage on a case where, for example, a young individual living in one of the institutional facilities commits a violent act against the facility staff or local residents. Then, the opinion of part of the Czech public radicalises (see, for example, Doubrava, 2004), which then receives its own media coverage. Unlike in public discourse, many experts perceive the criminality of children and youth as a consequence of their previous psychic deprivation (see, for example, Matějček, Bubleová, \& Kovařík, 2004). There are also cases of violation of children's rights by the institution (see the recent case in Chrastava with wide media coverage). ${ }^{49}$

46 See Lumos ("Pobyt dětí," 2015).

47 As a result of this current trend, there has been a decrease in the number of children in institutional care in the Czech Republic between years 2008-2013 by almost 2.000 (“Péče o ohrožené děti," 2014, p. 6).

48 Across the four sections, the priorities are: A. Participation of the child; B. Elimination of discrimination and unequal access for children; C. The right to family care and D. Ensuring the quality of life for children and families.

49 See Public Defender of Rights: Ombudsman ("Zařízení v Chrastavě," 2016). 
Vávrová, Vaculíková, \& Kalenda / Selected Aspects of Social and Legal Protection of Children...

The Ombudsman is the institute responsible for dealing systematically with human rights in residential facilities. ${ }^{50}$

\section{$4 \quad$ Methodology of public opinion inquiry}

The research was motivated by the interest to study opinions on current issues in social and legal protection of children across a representative sample of Czech adult population. We wanted to reveal the extent to which public opinion on the selected areas agrees with the opinions held by the expert discourse, as disagreement might hinder reforms of social and socio-pedagogical work.

The purpose of the research was to find out the public opinion on: (1) age limits of criminal liability; (2) provision of institutional or protective upbringing of children and youth with problematic behaviour (truancy, theft, use of addictive substances, criminal behaviour, etc.); and (3) preferences in selection of the form of replacement care of children and youth, and how this opinion may be affected by various agents such as gender, age, place of residence or region in which the respondent is based.

\subsection{Research Questions}

The research was based on the following research questions in order to formulate hypotheses to be confirmed or denied:

- What should be the age boundary of criminal liability?

- What is the public opinion on ordered institutional or protective upbringing of children and youth with problematic behaviour?

- What form of replacement care is generally considered most appropriate?

- Are there differences in answers to the above questions when considering different ages, education, places of residence or regionally based groups?

- Is the public acceptance of ordered institutional or protective upbringing different relative to the specified age limit of criminal liability? In other words, is the acceptance of ordered institutional or protective upbringing related to the selected age boundary of criminal liability?

- Is there any relationship between public acceptance of ordered institutional or protective upbringing of children and youth with problematic behaviour, their ages and acquired levels of education?

\subsection{Research and data collection methods}

The research was based on a quantitative methodological approach with use of the exploration inquiry method. The selected questions of social and socio-pedagogical work were part of a wider collection of items of the Omnibus data collection, implemented in Autumn 2015.

The questionnaire included socio-demographic items about gender and age (expressed in years and translated to the following age categories: $18-24$ years; $25-34$ years; $35-44$ years; $45-54$ years; $55-64$ years; 65 up), education (basic; secondary without school-leaving examination (apprenticeship); secondary with school-leaving examination; university level education), place of residence (city centre; off city centre; city outskirts, suburbs and villages close to big cities; villages; settlements and

50 See Public Defender of Rights: Ombudsman (“Zpráva ze systematických návštěv,” 2011). 
Vávrová, Vaculíková, \& Kalenda / Selected Aspects of Social and Legal Protection of Children... $\mid 64$

wilderness) $^{51}$ and geographic region (Prague; Central Bohemia; South West; North West; North East; South East; Central Moravia; Moravian Silesia) ${ }^{52}$.

Specific items about public perception of the selected issues (i.e., the boundary of criminal liability, consent with use of institutional and protective care and the preferred form of replacement care of parentless children and youth) were of nominal, ordinal and interval nature.

Data collection was performed by CAPI (Computer Assisted Personal Interviewing), on the basis of personal interviews by trained interviewers with assistance by electronic questionnaire. The interview took about 10 minutes. The filled-out questionnaires were checked visually and the data matrix was subject to both a formal and logical check of data completeness.

\subsection{Participants}

The research cohort included a representative sample of Czech adult population $(n=1.050)$. The selection of the sample was based on quotas for gender, age, education, place and region of residence (pursuant to the quotas of the Czech Statistical Office of 2012). Within the defined quotas the respondents were selected randomly by CAPI method ${ }^{53}$ until the quota was met. Thus, the research included (see Table 1) 501 males (48\%) and 549 females (52\%), with a mean age of 46 years (span 18 to $89, \mathrm{SD}=16.82$ years). For statistical purposes, the respondents were divided into six age groups shown in the Table 1 . Most respondents had acquired secondary education either without a school-leaving examination (36\%) or with a school-leaving examination (35\%). Elementary education was the highest education level achieved by $15 \%$ of the respondents and $14 \%$ were university graduates. Although half of the respondents lived in a city, most of them lived away from the city centre (51\%), $25 \%$ were village residents, $13 \%$ lived in city outskirts, suburbs and townships close to big cities (within $5 \mathrm{~km}$ ). The city centre was the place of residence of $11 \%$ of the respondents. The most heavily represented regions included South East (16\%) and North East (14\%). The other region representations fell between $11-12 \%$.

Table 1

Structure of selected research cohort

\begin{tabular}{|c|c|c|c|c|c|}
\hline & & \multicolumn{4}{|c|}{$\begin{array}{l}\text { Representative sample of Czech population } \\
\qquad(\mathrm{n}=1.050)\end{array}$} \\
\hline \multicolumn{2}{|c|}{ Socio-demographic characteristics } & $\mathrm{N}$ & $\%$ & $\mathrm{kn}_{\mathrm{i}}$ & $\mathrm{kn}_{\mathrm{i}}(\%)$ \\
\hline \multirow[t]{2}{*}{ Gender } & Male & 501 & 48 & 501 & 48 \\
\hline & Female & 549 & 52 & 1050 & 100 \\
\hline \multirow[t]{6}{*}{ Age } & $18-24$ years & 111 & 11 & 111 & 11 \\
\hline & $25-34$ years & 194 & 18 & 305 & 29 \\
\hline & $35-44$ years & 193 & 18 & 498 & 47 \\
\hline & $45-54$ years & 173 & 16 & 671 & 64 \\
\hline & $55-64$ years & 180 & 17 & 851 & 81 \\
\hline & 65 up & 199 & 19 & 1050 & 100 \\
\hline
\end{tabular}

51 Due to the low representation of respondents form settlements and the wilderness (2 respondents), no analysis for statistical significance for this category was conducted, as the total number of respondents were $n=1.048$.

52 In cases of non-compliance with the conditions of use of tests, there were fourteen original categories of nominal variables (administrative districts) combined to create eight geographic regions (these are listed in parentheses): Prague (Praha), Central Bohemia (Central Bohemia), South Bohemia and Pilsen (Southwest), Karlovy Vary Region and the Usti Region (Northwest), Liberec, Hradec Králové and Pardubice Region (Northeast), Vysocina and South Moravia (Southeast), Olomouc and Zlín Region (Central Moravia) and the Moravian Silesian Region (Moravian Silesia).

53 The method of data collection CAPI (Computer Assisted Personal Interviewing) presents interviews conducted by trained interviewers face-to-face with the respondents, aided by the help of laptops or tablets. 
Vávrová, Vaculíková, \& Kalenda / Selected Aspects of Social and Legal Protection of Children...

\begin{tabular}{llllll}
\hline Education & Elementary & 161 & 15 & 161 & 15 \\
& $\begin{array}{l}\text { Secondary without school-leaving } \\
\text { examination }\end{array}$ & 375 & 36 & 536 & 51 \\
& $\begin{array}{l}\text { Secondary with school-leaving examination } \\
\text { University }\end{array}$ & 368 & 35 & 904 & 86 \\
& City centre & 146 & 14 & 1050 & 100 \\
\hline Place of & & & 11 & 112 & 11 \\
residence & Off city centre & 535 & 51 & 647 & 62 \\
& Outskirts, suburbs and villages close to city & 135 & 13 & 782 & 74 \\
& (within 5 km) & & & & 100 \\
& Village & 266 & 25 & 1048 & 12 \\
& Prague & 130 & 12 & 130 & 24 \\
& Central Bohemia & 126 & 12 & 256 & 36 \\
& South West & 125 & 12 & 381 & 47 \\
& North West & 111 & 11 & 492 & 61 \\
& North East & 151 & 14 & 643 & 77 \\
& South East & 166 & 16 & 809 & 88 \\
& Central Moravia & 119 & 11 & 928 & 100 \\
\hline
\end{tabular}

Note: $k n_{i}=$ cumulative frequency, $k n_{i}(\%)=$ relative cumulative frequency.

\subsection{Data analysis and research results}

The research results evaluation was based on the predefined research questions and hypotheses. The hypotheses were tested by non-parametric methods of statistical data analysis. For the purpose of applicability test of the selected statistical methods (in the case of metric variables). KolmogorovSmirnov and Shapiro-Wils tests were used. The statistical test differences are significant on the significance level of .05 .

\section{(1) Boundary of criminal liability}

Descriptive statistics shows that 14 years of age most often (35\%) represented the adequate age for criminal liability limit. The second most frequently limits were 15 years of age $(31 \%)$ and 16 years of age (9\%). $22 \%$ of the respondents believed that the boundary of criminal liability should be assessed case by case, and $2 \%$ were unable to assess this fact (see Table 2 ). These results differ significantly, $x^{2}(4, n=1.050)=422.45, p<.001$.

Table 2

Age boundary of criminal liability

Representative sample of Czech population $(n=1.050)$

\begin{tabular}{lllll}
\cline { 2 - 5 } Age limits for criminal liability & $\mathrm{N}$ & $\%$ & $\mathrm{kn}_{\mathrm{i}}$ & $\mathrm{kn}_{\mathrm{i}}(\%)$ \\
\hline 14 years of age & 372 & 35 & 372 & 35 \\
15 years of age & 328 & 31 & 700 & 67 \\
16 years of age & 91 & 9 & 791 & 75 \\
Should be assessed individually & 233 & 22 & 1024 & 98 \\
Do not know, cannot assess & 26 & 2 & 1050 & 100 \\
Total & 1050 & 100 & 1050 & 100 \\
\hline
\end{tabular}

The descriptive statistics also suggest that the lowest age limit for criminal liability (14 years of age) was mostly preferred by respondents with secondary education, without a school-leaving examination $(38 \%, 141)$ and with a school-leaving examination $(35 \%, 130)$. The next most frequently mentioned limit was 15 years of age, most often suggested as the limit age for criminal liability by respondents who completed only elementary education $(34 \%, 55)$. On the other hand, university graduates tended to prefer 14 years of age as the criminal liability limit $(33 \%, 48)$ or individual 
assessment $(30 \%, 44)$. Although perception of the adequate age limit for criminal liability according to the highest acquired education of the respondents differed significantly, $x^{2}(12, n=1.050)=21.32$, $p=.046)$, the correlation tightness was too low (Cramer's $V=.08$ ). So, the discovered correlations, although statistically significant, ${ }^{54}$ do not represent significant circumstances.

The preferences related to the boundary of criminal liability significantly differed by region of residence of the respondents, $x^{2}(28, n=1.050)=55.6, p<.001$, Cramer's $V=.12$. According to the respondents from all regions except Prague, the boundary of criminal liability should be 14 years of age. Rounding out the overall ranking of the frequency of the individual variants, the second rank belonged to 15 years of age and the third rank to individual assessment. The age limit of 16 years seemed too high to most respondents from all regions and was therefore the least frequently mentioned (see Figure 2).

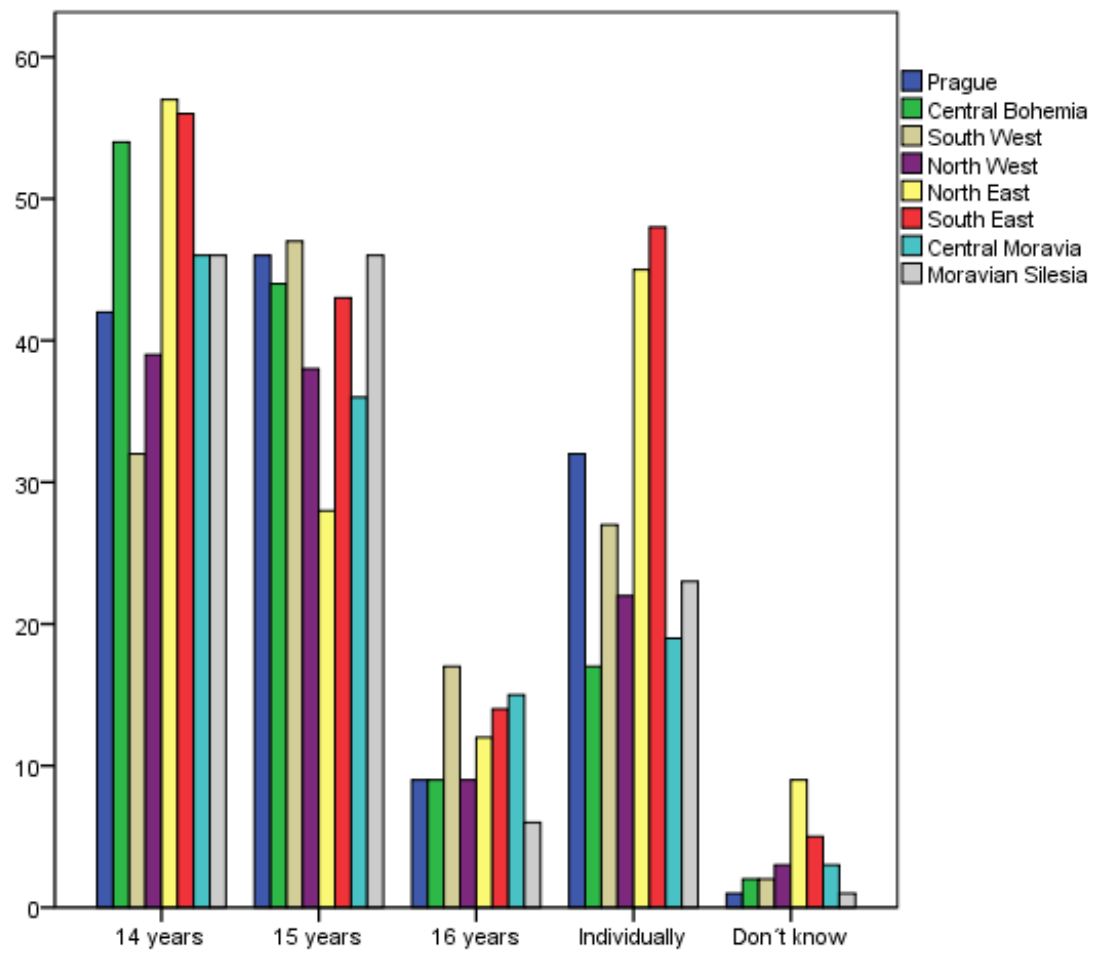

Figure 2 Boundary of criminal liability by region

\section{(2) Institutional or protective care}

The dominant majority of the respondents $(80 \%)$ agreed with ordering institutional or protective care to children and youth with problematic behaviour (such as truancy, theft, use of addictive substances, criminal behaviour, etc.). Nearly half of all respondents (45\%) strongly agreed. On the other hand, "I rather disagree" was used in this context by $11 \%$ and $3 \%$ of respondents strongly disagreed. About $7 \%$ of the respondents were unable to assess this, $x^{2}(4, n=1.050)=724.12$, $p<.001$.

54 Statistical significance is the likelihood that our sample comes from a set in which the null hypothesis is valid. At the same time, it makes the claim that a lower calculated level of significance would indicate higher statistical significance. But nothing more (Soukup, 2007). 


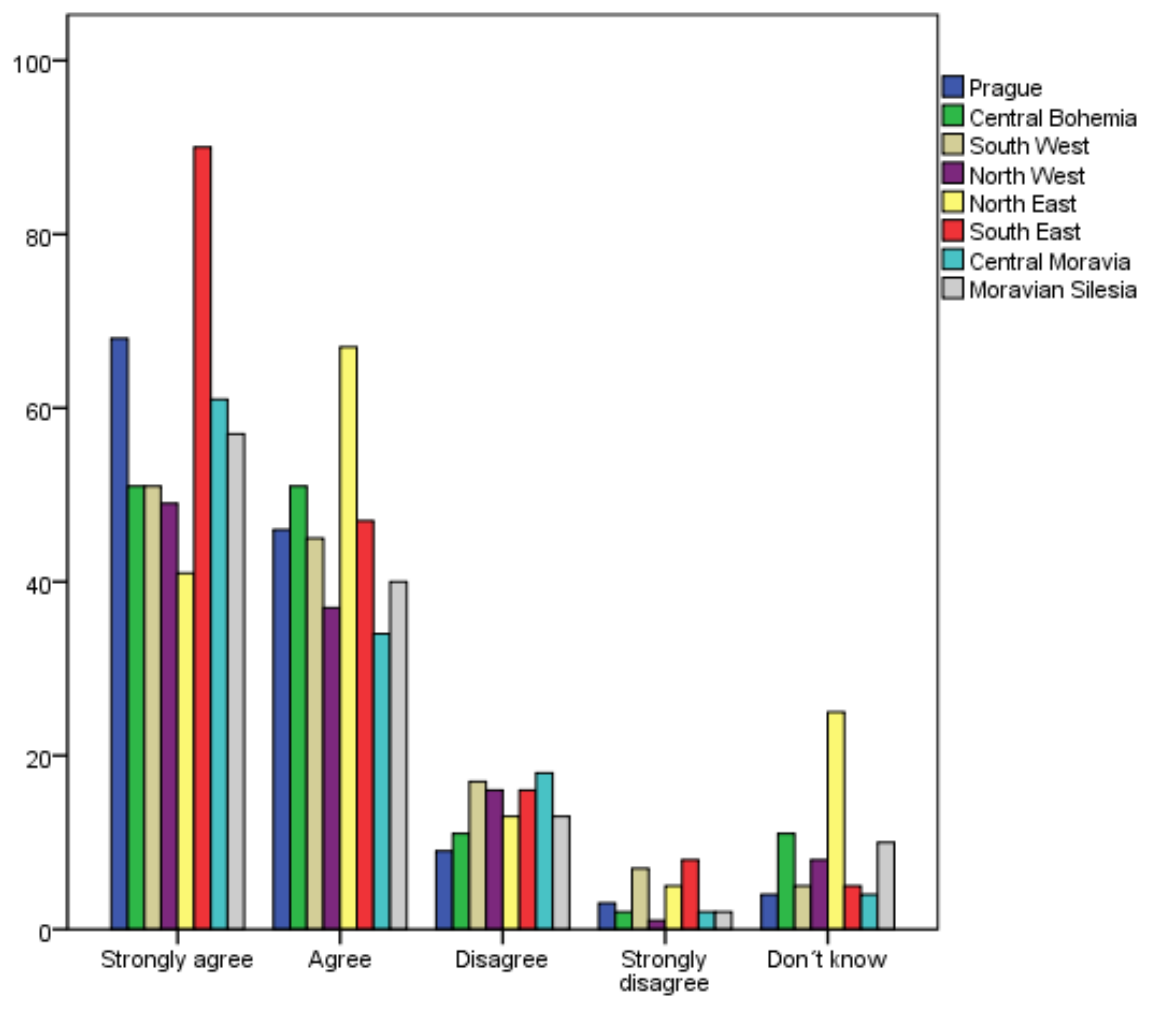

Figure 3 Acceptance of ordered institutional or protective care by region

Agreement with ordered institutional or protective care of children and youth with problematic behaviour differed by region, $x^{2}(28, n=1.050)=.267, p<.001$, Cramer's $V=.13$. Respondents from all regions (except South East and North West) mostly strongly agreed with ordered institutional or protective care. The trend of agreement/disagreement with ordered institutional or protective care from strongly agree to strongly disagree was descending (see Figure 3).

An interesting finding was that respondents strongly agreeing with ordered institutional or protective care mostly selected the lowest limit of criminal liability $(44 \%, 208)$. These respondents further recommended criminal liability from 15 years of age $(30 \%, 139)$ and individual assessment $(19 \%, 89)$. On the other hand, respondents not considering ordered institutional or protective care of children and youth with problematic behaviour an appropriate method of care mostly preferred higher limit of criminal liability of 15 years of age $(9 \%, 10)$ and individual assessment $(7 \%, 9)$. Nevertheless, no correlation was found between public acceptance of ordered institutional or protective care of children and youth with problematic behaviour, age and level of education achieved.

\section{(3) Replacement care}

The respondents considered foster care $(28 \%, 296)$ as the most appropriate form of replacement care of parentless children and youth. The following methods with insignificant differences in frequency were entrusting the child to care of another person (other than parents) $(25 \%, 264)$ and adoption $(24 \%, 254)$. Legal guardianship was considered the least appropriate form of replacement care of parentless children and youth $(5 \%, 50)$. These results differ significantly, $x^{2}(5, n=1.050)$ $=332.65, p<.001$.

Preferences in the form of replacement care of children and youth differed by place of residence of the respondent, $x^{2}(15, n=1.050)=38.31, p<.001$, Cramer's $V=.11$. Respondents living in a city centre most often preferred foster care $(31 \%, 168)$ and adoption $(27 \%, 143)$ and least frequently selected legal guardianship $(4 \%, 19)$. Respondents living in villages found entrusting the child to care 
of another person (other than parents) $(32 \%, 84)$ to be the most appropriate form of replacement care of children and youth. This was followed by foster care $(26 \%, 69)$ and adoption $(21 \%, 55)$.

The structure of selection of form of replacement care of parentless children and youthby gender and age is shown in Figure 4. Middle-aged females (25-34 years) preferred foster care, identical to males of the same age group. The overall preference across age groups was foster care, followed by entrusting the child to care of another person (other than parents) and adoption. Although the differences are not statistically significant $(p=.46)$, they represent an interesting finding.
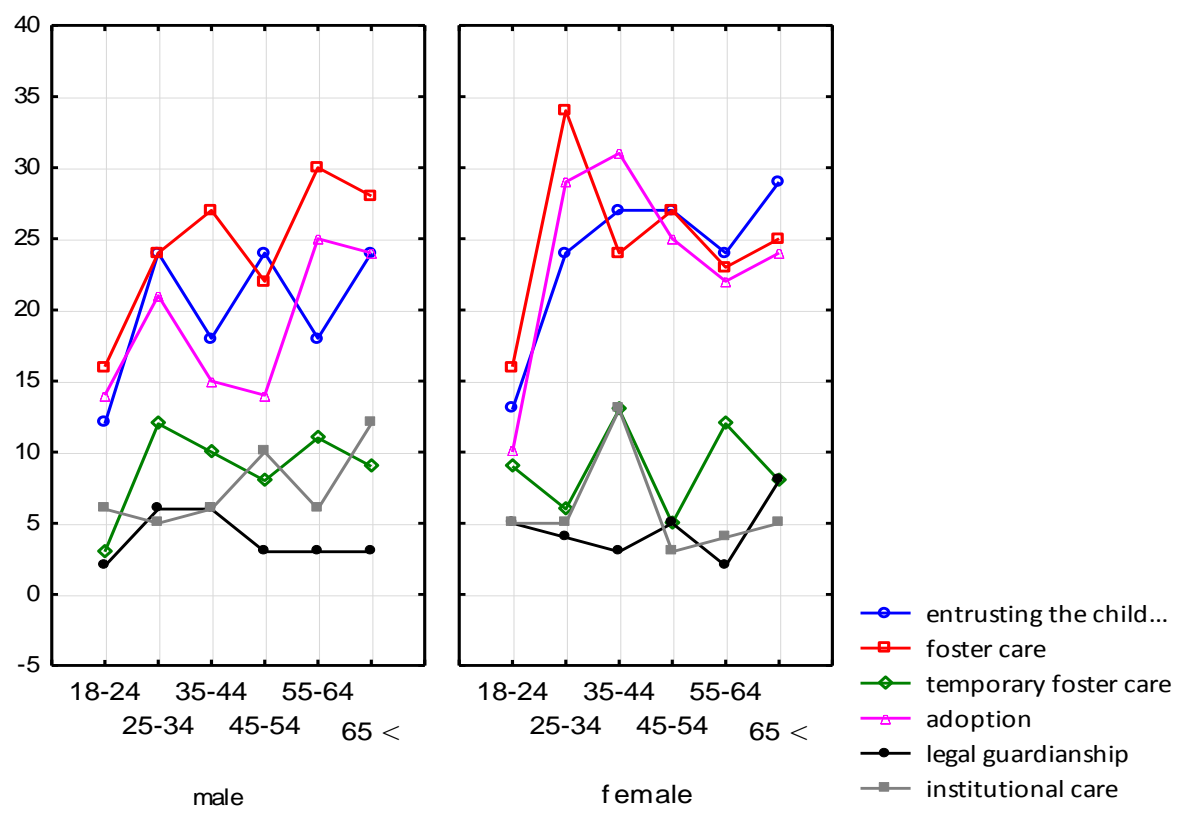

Figure 4 Form of replacement care of parentless children and youth by gender and age

University graduates showed a higher level of support for both variants of adoption compared to respondents with basic or secondary education. Another finding important to our conclusion was that only less than $8 \%$ considered institutional care as a suitable form of replacement upbringing.

\section{$5 \quad$ Final reflection - Expert vs. popular discourse}

The study shows that public opinion often addresses the same dilemmas as the expert discourse does, although using different argumentation platforms. While argumentation in expert discourse is based on scientific theories and obtained knowledge (about development of personality, child identity and effects of institutional environment on the child), the popular discourse is usually only supported by fragmentary media information and multiplied by the occasional media case, which then affects collective emotions, especially the feelings of worries and fear, as documented by Good and Ben-Yehuda (2009). By contrast, expert discourse is emotionally neutral, subject to control procedure within the research community and continuously critically assessed (Stehr \& Grundmann, 2011; Grundman \& Stehr, 2012).

What are the expert and popular discourse positions with respect to the three defined areas of social and legal protection of children: boundary of criminal liability, institutional or protective care and replacement care of parentless children? Our research allows for a conclusion that members of the general public are not unified in their opinions on the age limit of criminal liability and further, that those opinions do not agree with the main positions in the expert discourse. About one third of the respondents would prefer lowering the criminal liability age to 14 while another third agreed with the currently valid limit of 15 years. About one tenth would increase the limit even further to 16 
years. About one fifth believe that the boundary of criminal liability should be assessed individually, case by case.

The expert discourse (for instance, Elliott, 2011; Farmer, 2011; Hollingsworth, 2013; Svatoš, 2013; Bateman, 2014) rather take a defensive approach. Thus, regarding the boundary of criminal liability in the Czech Republic, we found the assumed contradiction between the popular and the expert discourse. However, the contradiction is typical not only for the Czech Republic but also for other countries where similar discussions are in progress (Cipriani, 2009; Farmer, 2011; Hollingsworth, 2016). One of the reasons for the fact that one third of Czech adult population would like to see the boundary lower might be the deeply rooted collective belief in "innocent childhood." According to Julie Fionda (2005), the author of "Devils and Angels: Youth Policy and Crime," modern western societies adhere to a relatively widely rooted concept of good-natured children. In Fionda's metaphor, a child is an "angel." If, however, a child commits a substantial offence against law and order or moral rules, it is very quickly - much more quickly than an adult - labelled a "devil." This is why the approach of part of the general public to child criminality is much more stringent than their approach to adult criminality. Representatives of the professional public should therefore focus more on education in this area and increase their emphasis on the argument against lowering the boundary of criminal liability.

Concerning education, we cannot see any simple linearity in the case of the boundary of criminal liability according to which decreasing level of achieved education would increase the gap between the expert opinion and opinion of that part of the public. On the other hand, people opposing raised limits of criminal liability are represented at all education levels. So, the education obtained and any related cultural capital therefore cannot shed any light on public opinion.

Another non-surprising finding is the fact that the respondents who chose the lowest offered limit of criminal liability (14 years) absolutely agreed with the ordered institutional or protective care of children and youth with problematic behaviour. On the other hand, respondents not supporting ordered institutional or protective care of children and youth with problematic behaviour as an appropriate method of their support most often preferred the higher limit of criminal liability (15 years).

On the whole, the trend seen in the area of preferred form of replacement care of parentless children and youth across all age groups was as follows: (1) foster care, (2) entrusting the child to another natural person (other than parents) for care, (3) adoption, (4) care for a limited period of time and only then (5) institutional care (children's home). The above hierarchy shows that the discourse of non-institutionalisation of children and youth is deeply rooted in Czech society: only $8 \%$ of the respondents considered replacement care by an institution (children's home) the most appropriate method of child care. In this respect, there are in fact no contradictions between the expert approach to replacement family care and the public opinion (see, for example, Běhounková, 2012; Chrenková, Cilečková, \& Hašková, 2015; Vávrová, Hrbáčková, \& Hladík, 2015). Unlike the case of the boundary of criminal liability, an important role in this context was probably played by an extensive educational campaign as well as the fact that media covered problems of institutional care rather than those of non-institutional care. Non-institutional care has never become a target of extensive moral panic or raised public opinion against it.

However, a contradiction between the popular and the expert discourse was observed in the third area of preference of temporary foster care. Temporary foster care, through the eyes of expert discourse, is a necessary element of non-institutional replacement care, without which the contemplated transformation could hardly be implemented (see, for example, Cilečková, 2014; Vávrová \& Kroutilová Nováková, 2015). This is not reflected in the public opinion. This fact may be the result of extensive media discussions where some critics of de-institutionalisation in this area insisted that this is no longer care but rather a "sheer business." ${ }^{155}$ If public opinion and expert

55 See, for example, Regional news („Roste počet,“ 2016). 
Vávrová, Vaculíková, \& Kalenda / Selected Aspects of Social and Legal Protection of Children... $\mid 70$

discourse should get closer to each other in the case of this problem, then more attention will need to be paid to the educational agenda in order to broaden the awareness of the positive aspects of non-institutional replacement care.

The implemented research confirms our initially formulated theoretical assumption of the existence of two different approaches to issues of social and socio-pedagogical work. Public opinion on certain issues of social and legal protection of children is considerably different from positions recently defended and asserted by the expert discourse, and thus can stand in opposition against ongoing reforms in the area of social and legal protection of children.

Nevertheless, public opinion does not always oppose the opinions of experts. As shown in the example of institutional care of children and youth, the general public (like the expert discourse) disagrees with institutionalisation. This condition is probably the result of long and systematic education provided by experts, helping the idea of de-institutionalisation take root in Czech society across age groups and groups with different levels of education and socio-economic standing.

In the light of the broad concept of social pedagogy (see, for example, Kraus \& Poláčková et al., 2001; Kraus, 2008; Bakošová, 2008), the results of our research are relevant for the discipline, showing that despite the extensive accumulation of scientific knowledge in the past decade, the Czech lay population still holds opinions completely different from the expert discourse. If social pedagogy aims to "focus on the population as a whole in the sense of creation of harmony between needs of the individual and the society and creation of the optimum way of life in the society" (Kraus, Poláčková et al., 2001, p. 12), then it must obviously also focus on: (1) Study of phenomena that are not in accord with the desires of part of the society and the expert public, especially if the expert public is represented by social and pedagogical workers whose knowledge and recommendations are to serve to improve the society's way of life, as insisted by Kraus, Poláčková and others (2001); (2) Attempts to overcome the disharmony through systematic educational activity; (3) Pointing out how extreme opinions (as opposed to expert knowledge) are misused to raise moral panic and create even greater disharmony between individuals and in the society, thus requiring recommendations for the solution of the issues in question.

In other words, social pedagogy should increasingly focus on: (1) Further study of harmonies and disharmonies between expert and popular discourse concerning phenomena within its area of action; (2) Reduction of the differences between the two discourses by acquiring empirical knowledge of the attitudes in public discourse, allowing identification of major social groups who oppose the expert discourse, in turn helping the better planning of targeted social, pedagogical and educational activities; (3) Social pedagogues should actively contribute to the ongoing discussions and engage in assertion of the desired positive changes not only in the area of social and legal protection of children among general public.

\section{References}

Act No. 218/2003 Coll., on liability juveniles for illegal acts and on juvenile justice and amending certain acts (juvenile justice). (2016, September 10). Zákony pro lidi. Retrieved from http://www.zakonyprolidi.cz/cs/2003-218

Act No. 359/1999 Coll., on child protection. (2016, September 10). Zákony pro lidi. Retrieved from http://www.zakonyprolidi.cz/cs/1999-359

Act No. 40/2009 Coll., on criminal code. (2016, September 10). Zákony pro lidi. Retrieved from http://www.zakonyprolidi.cz/cs/2009-40

Act No. 89/2012 Coll., on civil code. (2015, September 10). Zákony pro lidi. Retrieved from http://www.zakonyprolidi.cz/cs/2012-89

Arthur, R. (2012). Rethinking the Criminal Responsibility of Young People in England and Wales. European Journal of Crime, Criminal Law and Criminal Justice, 20(1), 13-29. 
Vávrová, Vaculíková, \& Kalenda / Selected Aspects of Social and Legal Protection of Children... 71

Bakošová, Z. (2008). Sociálna pedagogika ako životná pomoc. Bratislava: Univerzita Komenského v Bratislave.

Bateman, T. (2014). "Catching them young" - Some reflections on the meaning of the age of criminal responsibility in England and Wales. Safer Communities, 13(3), 133-142. doi:10.1108/SC-052014-0008

Bauer, J. (1995). Pěstounská péče v zrcadle výzkumu. Práce \& sociální politika, 21(6), 13-14.

Běhounková, L. (2012). Fenomén odchodu do samostatného života dítěte vyrůstajícího v náhradní výchovné péći. Prague: Togga.

Best, J. (2008). Social Problems. New York: Norton.

Bittner, P. (Ed.). (2007). Děti z ústavů!: Právní a psychologické dopady ústavní výchovy z pohledu ochrany rodiny a nejlepšího zájmu dítěte. Brno: Liga lidských práv.

Chrenková, M., Cilečková, K., \& Hašková, A. (2015). Faktory ovlivňující formu náhradní rodinné péče [Factors affecting the form of substitute family care]. Sociální pedagogika, 2(3), 38-50. doi:10.7441/soced.2015.03.02.03

Cilečková, K. (2014). Změny v náhradní rodinné péči. Sociální práce, 14(2), 61-70.

Cipriani, D. (2009). Children's rights and the minimum age of criminal responsibility: A global perspective. Surrey: Ashgate.

Congress Legislative Space for a Sixth Time. (2016, May 20). Bulletin advokacie. Retrieved from http://www.cak.cz/assets/komora/bulettin-advokacie/ba_05_2016_web.pdf

Dearing, J. W., \& Everett, M. R. (1996). Agenda-Setting. Thousand Oaks, London: Sage.

Doubrava, L. (2004, May 14). Dětské vězení jako jediné řešení? Učitelské noviny. Retrieved from http://www.ucitelskenoviny.cz/?archiv\&clanek=5065

Elliott, C. (2011). Criminal responsibility and children: A new defence required to acknowledge the absence of capacity and choice. The Journal of Criminal Law, 75, 289-308. doi:10.1350/jcla.2011.75.4.717

Erikson, E. H. (2015). Životní cyklus rozšířený a dokončený: Devět věků člověka. Prague: Portál.

Farmer, E. (2011). The age of criminal responsibility: Developmental science and human rights perspetives. Journal of Children's Services, 6(2), 86-95. doi:10.1108/17466661111149385

Fionda, J. (2005). Devils and angels: Youth policy and crime. Abingdon: Hart.

Giddens, A. (1998). Důsledky modernity. Prague: SLON.

Glaeser, A. (2006). An ontology for the ethnographis analysis of social processes: Extending the extended case method. In T. M. S., Evens, \& D. Handelman (Eds.), The Manchester School: Practice and etnographic praxis in anthropology (pp. 64-99). New York: Berghahn Books.

Goertz, G., \& Mahoney, J. (2012). A tale of two cultures: Qualitative and quantitative research in the social science. Princeton: Princeton University Press.

Goode, E., \& Bem-Yehuda, N. (2009). Moral panics: The social construction of deviance. New York: Wiley-Blackwell.

Grisso, T., Steinberg, L., Woolard, J., Cauffman, E., Scott, E., Graraham, S., Lexcen, F., Repucci, N., \& Schwartz, R. (2003). Juveniles competence to stand trials: A comparison of adolescence and adults capacities as trial defenders. Law and Human Bahavior, 27(4), 333-363.

Grundmann, R., \& Stehr, N. (2012). The power of scientific knowledge. From research to public policy. Cambridge: Cambridge University Press. 
Vávrová, Vaculíková, \& Kalenda / Selected Aspects of Social and Legal Protection of Children...

Gulová, L. (2012). Aktivizace sociálně znevýhodněných skupin v pedagogické praxi a výzkumu. Brno: Masarykova univerzita.

Hollingsworth, K. (2013). Theorising children's rights in youth justice: The significance of autonomy and foundational rights. Modern Law Review, 76(6), 1046-1069. doi:10.1111/14682230.12047

Hollingsworth, K. (2016). The utility and futility of international standards for children in conflict with law. In L., Weber, L.; Fishwick, E., \& Marmo, M. (Eds.). The Routledge international handbook of criminology and human rights. New York: Routledge.

Horáková, N. (2016, October 10). Co je pro nás morálně přijatelné? (Etické otázky ve výzkumu veřejného mínění). SOClO web. Retrieved from http://www.socioweb.cz/index.php@disp=teorie\&shw=221\&lst=106.html

Hrbáčková, K., \& Petr Šafránková, A. (2015). Vnímání vlastní účinnosti pedagogických pracovníků $\checkmark$ oblasti institucionální péče [Self-efficacy of professional educators in institutional care for children and minors]. Sociální pedagogika, 3(2), 9-24. doi:10.7441/soced.2015.03.02.01

Hulmáková, J. (2016, March 29). Hranice trestní odpovědnosti v kontextu trendů kriminality mládeže a v evropském srovnání. Poslanecká sněmovna Parlamentu České republiky. Retrieved from http://www.psp.cz/doc/pdf/00/08/49/00084976.pdf

Janský, P. (2009). Náhradní výchovná péče a její transformace. Učitelské noviny: Týdeník pro učitele a prátele školy, 112(21), 17-19.

Janský, P. (2014). Dítě s problémovým chováním a náhradní výchovná péče ve školských zařizeních pro výkon ústavní a ochranné výchovy. Hradec Králové: Gaudeamus.

Klusák, M. (2014). Morální vývoj školáků a předškoláků: Paradigmatické výzvy dle Jeana Piageta. Prague: Karolinum.

Knorr-Cetina, K. (1999). Epistemic cultures. How the sciences make knowledge. Harvard: Harvard University Press.

Kovařík, J. (1998). Dlouhodobé sledování dětí, které vyrůstaly v náhradní péči. Náhradní rodinná péče, 2, 18-28.

Kraus, B. (2008). Základy sociální pedagogiky. Prague: Portál.

Kraus, B., \& Poláčková, V. (Ed.). (2001). Člověk - prostředí - výchova: K otázkám sociální pedagogiky. Brno: Paido.

Kubíčková, H. (2011). Dítě - rodina - instituce, aneb, Jak neztratit budoucnost. Ostrava: Ostravská univerzita.

Loseke, D. (1999). Thinking about social problems: An introduction to constructionist perspective. New York: Aldine de Gruyter.

Matějček, Z. (1998). Desatero pro náhradní rodiče. Náhradní rodinná péče, 2, 35-36.

Matějček, Z., \& Dytrych, Z. (1994). Děti, rodina a stres: Vybrané kapitoly z prevence psychické zátěže u dětí. Prague: Ministerstvo zdravotnictví ČR.

Matějček, Z., Bubleová, V., \& Kovařík, J. (2004). Kriminalita jako následek psychické deprivace. In J. Kovařík (Ed.)., Náhradní rodinná péče v praxi (pp. 109-114). Prague: Portál pro Středisko náhradní rodinné péče.

McCombs, M. E. (2009). Agenda setting. Prague: Portál.

McDiarmid, C. (2013). An age of complexity: Child and criminal responsibility in law. Youth Justice, 13(2), 145-160. doi:10.1177/1473225413492056 
Vávrová, Vaculíková, \& Kalenda / Selected Aspects of Social and Legal Protection of Children... 73

Národní akční plán k transformaci a sjednocení systému péče o ohrožené děti na období 2009-2011 (2009, January 9). Ministry of Labour and Social Affairs (MLSA). Retrieved from http://www.mpsv.cz/files/clanky/7440/NAP.pdf

Návrh opatření k transformaci a sjednocení systému péče o ohrožené děti - Základní principy. (2009, January 9). Ministry of Labour and Social Affairs (MLSA). Retrieved from http://www.mpsv.cz/files/clanky/9556/Navrh_opatreni_k_transformaci.pdf

Novák, T. (2008). Slasti a strasti pěstounů. Psychologie dnes, 14(10), 32-33.

Péče o ohrožené děti v České republice. (2014, November 11). Lumos Foundation. Retrieved from http://czech.wearelumos.org/sites/default/files/material-seminar11-11.pdf

Pilař, J. (2005). Náhradní výchovná péče v nahotě reality. Učitelské noviny: Týdeník pro učitele a prátele školy, 108(36), 16-17.

Pobyt dětí ve velkých ústavech poškozuje jejich zdravý vývoj, tvrdí odborné studie. (2015, February 17). Lumos Foundation. Retrieved from http://czech.wearelumos.org/node/180

Punová, M. (2015). Práce s mládeží v době nejisté [Youth Work in Times of Uncertainty]. Sociální pedagogika, 3(1), 70-84.

Ragin, Ch. (2000). Fuzzy-set social science. Chicago: University of Chicago Press.

Ragin, Ch. (2009). Redesigning social inquiry: Fuzzy sets and beyond. Chicago: University of Chicago Press.

Říčan, P. (2014). Cesta životem: Vývojová psychologie. Prague: Portál.

Roste počet profesionálních pěstounů za peníze. Dělají si opravdu z dětí byznys? A kolik jim stát platí? Čtěte tvrdá fakta i názory z obou stran. (2015, February 2). Regional news. Retrieved from http://www.krajskelisty.cz/praha/7808-roste-pocet-profesionalnich-pestounu-za-penize-kolikdostavaji-a-proc-jim-lide-nadavaji-ze-z-deti-delaji-byznys-ctete-tvrda-fakta-i-nazory-z-oboustran.htm

Škodová, M., \& Nečas, V. (Eds.). (2009). Veřejná a mediální agenda: Komparativní analýza a tematizace veřejné sféry. Prague: Professional Publishing.

Slavíková, A., \& Horáková, Z. (2014, March 17). Mnoho dětí z dětských domovů nechce do pěstounské péče. Deník.cz. Retrieved from http://www.denik.cz/kraj-vysocina/mnoho-deti-zdetskych-domovu-nechce-do-pestounske-pece-pe14-e37v.html

Sobotková, I., \& Očenášková, V. (2013). Pěstounská péče očima dospělých, kteří v ní vyrostli: Trendy vs. zkušenosti. Olomouc: Univerzita Palackého v Olomouci.

Soukup, P. (2007, June 1). Statisticky významný neznamená důležitý. SOCIO web. Retrieved from http://www.socioweb.cz/index.php@disp=teorie\&shw=298\&lst=112.html

Spector, M., \& Kitsuse, J. I. (1977). Constructing social problems. Menlo Park: Cummings.

Stanoev, N. (2014). Cesta k závislosti a zpět [The path to addiction and back]. Sociální pedagogika, 2(1), 64-81. doi:10.7441/soced.2014.02.01.05

States lowering age of criminal responsibility. (2016, November). Child Rights International Network (CRIN). Retrieved from https://www.crin.org/en/home/what-we-do/policy/stop-makingchildren-criminals/states-lowering-age-criminal-responsibility

Stehr, N. (2001). The fragility of modern societies: Knowledge and risk in the information age. London: Sage.

Stehr, N., \& Grundmann, R. (2011). Experts: The knowledge and power of expertise. London: Routledge. 
Vávrová, Vaculíková, \& Kalenda / Selected Aspects of Social and Legal Protection of Children...

Stone, D. (2011). Policy paradox: The art of political decision making. New York: Norton.

Svatoš, R. (2013). Vývoj kriminality mládeže v České republice. Kriminalistika, 46(2), 139-154.

Svoboda, Z. (Ed.). (2012). Etopedické propylaje l.: Aktuální otázky systému náhradní výchovné péče o jedince s poruchou chování. Ústí nad Labem: Univerzita J. E. Purkyně.

Svobodová, M. (2003). Zpráva o stávajícím stavu náhradní rodinné péče o děti a mládež bez rodinného zázemí v české republice. Sociální práce, 2, 28-45.

Tab. č. 65 Zařízení pro výkon ústavní a ochranné výchovy - Přehled zařízení podle území. (2015, October 15). Czech Statistical Office. Retrieved from https://www.czso.cz/documents/10180/20555525/2300421565.pdf/144bea1f-44d0-463d$82 \mathrm{cc}-1 \mathrm{~d} 8 \mathrm{ba0390a56?version}=1.0$

Tejc navrhuje snižení hranice trestní odpovědnosti na 13 let. (2016, February 28). Novinky.cz. Retrieved from https://www.novinky.cz/domaci/396129-tejc-navrhuje-snizeni-hranice-trestniodpovednosti-na-13-let.html

Thorová, K. (2015). Vývojová psychologie: Proměny lidské psychiky od početí po smrt. Prague: Portál.

Toman, J. (1994). Náhradní výchova a speciální výchovná zařizení z pohledu společenských změn. Mládež, společnost a stát, 4, 19-24.

Válková, H., \& Hulmáková, J. (2008, October 7). Odborníci: Hranici trestní odpovědnosti není nutné snižovat. Retrieved from http://zpravy.idnes.cz/odbornici-hranici-trestni-odpovednosti-neninutne-snizovat-prt-/zpr_archiv.aspx?c=A081003_114748_kavarna_bos

Vaughan, D. (2014). Theorizing: Analogy, cases, and comparative social organization. In R. Swedberg (Ed.)., Theorizing in social science: The context of discovery (pp. 61-84). New York: Oxford University Press.

Vávrová, S., \& Kroutilová Nováková, R. (2015). Transformace systému péče o ohrožené děti očima reditelů dětských domovů [Transformation of the system of care for vulnerable children from the perspective of children's homes' directors]. Sociální pedagogika, 3(2), 25-37. doi:10.7441/soced.2015.03.02.02

Vávrová, S., Hrbáčková, K., \& Hladík, J. (2015). Porozumění procesu autoregulace u dětí a mladistvých $v$ institucionální péči. Zlín: Tomas Bata University in Zlín.

Vávrová, S., Musilová, D., \& Polepilová, R. (2014). Názory studentů vybraných pomáhájících profesí na rušení ústavních zařizení pro děti do tří let věku v kontextu současných změn [Opinions on the closure of institutional facilities for children up to 3 years in the context of recent changes among students of selected helping professions]. Sociální pedagogika, 2(1), 82-99. doi:10.7441/soced.2014.01.06

Yin, R. K. (2002). Case study research. Design and methods. 3rd edition. Thousand Oaks: Sage.

Zařizení v Chrastavě deset let neplnilo své povinnosti. (2016, July 7). Public Defender of Rights: Ombudsman. Retrieved from http://www.ochrance.cz/aktualne/tiskove-zpravy-2016/zarizeniv-chrastave-deset-let-neplnilo-sve-povinnosti

Zezulová, D. (2012). Pěstounská péče a adopce. Prague: Portál.

Zpráva ze systematických návštěv. Školských zařízení pro výkon ústavní výchovy a ochranné výchovy. (2011). Public Defender of Rights: Ombudsman. Retrieved from http://www.ochrance.cz/fileadmin/user_upload/ochrana_osob/2012/2012_skolskazarizeni.pdf 